\title{
Post-exceptional politics in agriculture: an examination of the
}

\section{CAP reform}

\section{Alan GREER}

\begin{abstract}
A core claim about agricultural policy making is that it is 'compartmentalized' and 'exceptional'. In this picture, the policy process is insulated from other policy concerns, has a distinctive system of actors and institutional structures, and rooted in extensive governmental intervention in the market and the re-distribution of resources from taxpayers to food producers.
\end{abstract}

Recently there have been suggestions that a 'post-exceptional' agricultural politics has emerged, which is more market-driven, has reduced state intervention, and where policies reflect influences relating to non-food issues such as the environment. This contribution discusses the concepts of compartmentalization and exceptionalism and then applies 'indicators of change' to a case study of the 2013 reform of the Common Agricultural Policy (CAP). It concludes that the reform provides evidence for 'shallow' post-exceptionalism where a historically persistent 
agricultural policy subsystem has opened up to new actors, incorporated some programme change but left the ideational framework largely intact.

Keywords: agricultural politics, Common Agricultural Policy, CAP reform 2013, compartmentalization, exceptionalism, post-exceptionalism.

\section{Introduction}

A central element in the historically dominant picture of agricultural policy is that decision making takes place in a subsystem with a distinctive set of actors and institutional structures that is insulated from other policy concerns (a 'compartmentalised' policy process) and that policy instruments and programmes reflect a particular form of state intervention that differs from rules that generally apply to other major sectors of the economy ('exceptionalism'). The agricultural policy subsystem has been underpinned by ideational congruence, a consensus over values that marginalises some non-farm actors, and which produces policy outcomes that favour privileged interests. In recent years, attention has turned to the possibilities for a 'de-compartmentalised' and 'post-exceptional' agricultural politics (see Daugbjerg and Feindt, Introduction to this issue). In terms of process, this would mean that policy concerns relating to issues such as the environment and climate change (all 'messy' problems that tend to cut across the traditional boundaries of policy making) have become increasingly important; in relation to 
instruments and programmes, that the highly interventionist role of government has weakened.

This contribution uses four indicators of change that relate to institutions, actors, ideas and programmes to assess whether the 2013 reforms of the Common Agricultural Policy (CAP) provide evidence for post-exceptional agricultural politics. Broadly the contribution considers the impact of inter-institutional policy making and examines the tensions between the persistence of a strong agricultural policy heritage (that strongly emphasises food security and production), and a more open, contested and networked politics that reflects a broader range of issues. It concludes that the reform provides evidence for what may be termed 'shallow' postexceptionalism - some movement from a historically persistent agricultural policy subsystem involving the inclusion of some new actors and some programme change but which leaves the ideational framework largely intact.

\section{Exceptionalism and Post-exceptionalism}

Much of the academic literature on agricultural policy has emphasised 'compartmentalization', 'exceptionalism', and the dominance of a 'state-assisted' paradigm (see Coleman et al. 1997; Rieger 2000; Roederer-Rynning 2010; Skogstad 1998). Writing on the CAP for example, Grant noted that while the circle of actors involved in the policy process had widened in the early 1990s, agricultural policy remained 'highly compartmentalised', with a 'high political entry barrier into the policy community' (1997: 148). In this picture, the institutional configuration - at 
national and EU levels - has been made up of distinctive actors that are contained within relatively impermeable boundaries. The agricultural policy subsystem centred on food production - is highly insulated from other policy subsystems such as the environment, and the influence of actors who are not central to the core of the subsystem is limited.

'Exceptionalism' highlights a durable interpretive framework, how policy ideas, values and norms are embedded within institutional structures, and shape policy programmes. As defined by Skogstad, it is the 'idea that agriculture is a sector unlike any other economic sector, and, as such, warrants special government support'. This in turn provides the underpinning for the development of the 'state assisted paradigm' with its associated government intervention in relation to regulation and expenditure (1998: 468). The concept of agricultural exceptionalism therefore 'describes the special treatment of the agricultural sector by governments and international organizations, and the belief system that provides cognitive justification and political legitimation' (Daugbjerg and Feindt, Introduction to this issue: 1$)$.

Bringing compartmentalization and exceptionalism together, Daugbjerg and Feindt note that the agricultural policy subsystem has been characterized 'by a distinct set of sector-oriented institutions and ideas', 'substantial government intervention in the market', and the redistribution of resources to a 'relatively small group of producers and land owners' (Introduction to this issue: 1). A key part of this picture is the emphasis on policy networks, an approach well-suited to established policy subsystems such as agriculture where the status quo is reinforced by ideational 
consensus around the nature of food production (for a summary see Greer 2005: 2330; Marsh and Smith 2000). Agriculture policies and associated institutions have been protected by established decision-rules and dominant policy communities. The idea of closed policy communities has been especially prevalent, drawing attention to stable interactions and bargaining over time between state 'agriculture' departments and well-resourced groups representing farmers, based on consensus around values, with largely incremental policy outcomes (Smith 1992).

What then would 'post-exceptional' agricultural policy look like? In the first instance it would involve the weakening of the historically dominant closed policy communities centred on farmers and the emergence of more 'open' network governance involving a wider range of actors, struggles between competing interests, and corresponding shifts in the nature of policy interventions. There is some evidence for this over the last twenty five years, indicating that policy crisis and exogenous pressures (relating for example to trade liberalisation) can be crucial factors. In the context of BSE and other food crises in the UK for instance, some analysts identified the emergence of an issue network type structure with a wider range of pressure participants in addition to the historically dominant farmers' organizations (see Grant 2004; Jordan et al. 1994; Smith 1991). Certainly there has been a broadening of the policy agenda, with the inclusion within the agriculture subsystem of issues such as environmental sustainability, rural development and climate change, alongside the traditional focus on food security and production. However such issues can be absorbed into an agricultural paradigm, as is shown in the creation of the Department of the Environment, Food and Rural Affairs (Defra) 
in the UK (Winter 2003: 51) and there is disagreement over whether the configuration of institutions and actors has been substantially reshaped. So while Woods (2005) referred to the 'collapse' of the agricultural policy community, for others the policy process on the 2001 outbreak of foot-and-mouth disease (FMD) in the UK provided 'little evidence for the emergence of an issue network' and the outcomes 'exhibited a degree of continuity far more consistent with a policy community' centred on the historically powerful farmers' organizations (Wilkinson et al. 2010: 337-8).

A second element relates to a weakening of the 'state assistance paradigm' and the historically high degree of government intervention in the policy subsystem. In Skogstad's argument paradigm change 'is indicated by deregulation of agricultural markets, the termination or substantial restraint of government expenditures for agriculture, and a discourse antithetical to government intervention' (1998: 471). Here there also is disagreement. For some, cumulative change to the CAP including under the MacSharry reforms (1992) and the Fischler package (2003) represents a decisive ideational shift in policy values and in instruments that has substantially weakened the producer interest, illustrated for example by the move away from direct support for production to decoupled area payments. Burrell (2009) charts a pattern of continuous reform from a highly centralized protectionist policy focused on farm incomes to one that is more market sensitive and environmentally sustainable. For others continuity is emphasized within the framework of the stateassisted paradigm (although it may include the incorporation of new objectives), exemplified in stable budgets and patterns of redistribution, persisting institutional 
settings and path dependence. As Daugbjerg and Feindt note 'we almost face a paradox with much change in policy instruments, ideas and discourses while farm income remains the unaffected "policy core" with relatively stable redistribution of resources into the farm sector' (Introduction to this issue: 4).

Yet policy change should not be viewed as a one-way process. The notion of 'sequencing' shows how changes to the CAP are not necessarily in the same direction and that each reform event opens possibilities for further 'reform' (Daugbjerg 2009). A reversal to older institutional logics is also possible. While Erjavec et al. (2008) argue that the policy discourse of (Agriculture Commissioners) Fischler and Fischer-Boel reflected a neo-liberal rhetoric, others claim that the tenure of Cioloss saw a shift back to the state-assisted position in which subsidies are defended as a way to ensure a fair and efficient European agriculture (Rutz et al. 2014).

In this context, 'post-exceptionalism' can be used as a diagnostic concept that highlights both continuity and change in the agricultural policy subsystem. For Daugbjerg and Feindt, the value of the concept is that it captures 'the combination of a less compartmentalized policy arena' with ideas that 'retain claims that a policy sector is special, albeit with updated arguments that relate to the problems on the evolving policy agenda (e.g., sustainability, climate change) and which trigger novel policy instruments' (Introduction to this issue: 8). As they summarize, there is 'a set of exceptionalist ideas which legitimize a set of compartmental institutions that provide a dedicated policy space for a policy community to adopt and implement policy instruments and programmes that serve their interests and comply with their 
ideas' (original italics, Introduction to this issue: 4). Drawing on these insights, there are four dimensions that can be used as to develop indicators for the emergence of a post-exceptional agricultural politics:

1. Changes to the institutional structure of the policy subsystem;

2. The incorporation of 'new' actors and interests;

3. A weakening of the dominant ideational structure, with the introduction of conflicting values, new policy areas and ideas; and

4. A weakening of policy stability, with policy change reflected in instruments and programmes.

In what follows, these four 'indicators of change' are applied to an analysis of the 2013 reform of the CAP.

\section{CAP Reform 2013}

There is considerable disagreement about whether agricultural policy reform can be viewed as radical and extensive, or minimal and incremental. Proponents of the latter emphasise the obstacles in the way of CAP reform, sometimes using ideas about historical institutionalism and path-dependence (Kay 2003). Incremental policy change leaves the 'state-assisted' paradigm largely intact. This is the result of bargaining between actors in which the key factors are the preferences and institutional structures of member states (brought together in the Agriculture Council), with the Commission playing a crucial role in setting the agenda, both 
buttressed by closed producer-dominated agricultural policy communities. Nonetheless change does happen, often as a result of wider policy ideas and exogenous factors such as trade liberalisation and budget reform, which may be important in weakening the compartment from the outside (Daugbjerg and Swinbank 2009; Lynggaard and Nedergaard 2009). Moreover, incremental policy change can have substantial cumulative effects over time (see Ackrill 2000; Cunha 2011; Keeler 1996; Swinbank 1999; Swinnen 2009).

Following initial consultations in spring 2010 about the CAP after 2014, the EU Commission's Directorate General for Agriculture and Rural Development (DG Agri) published legislative proposals in October 2011 (European Commission 2010, 2011 b \& c; Swinbank 2012). After protracted negotiations, a political deal was reached on 26 June 2013, with everything finalised in the autumn. As one contemporary report put it, agreement came 'after months of haggling over how ambitious the policy would be on overhauling direct payments, ending quotas, and making farmers more environmentally accountable' (Spence 2013).

Wider negotiations about the Multiannual Financial Framework (MFF) for 2014-2020 were an important influence on the CAP reform debate. Here there were pressures for a radical reorientation of priorities and for lower spending in the context of austerity, which would inevitably mean a reduction in the agriculture budget (Greer 2013, 2012). Matthews (2015) identifies three linkages between the MFF and CAP negotiations: (1) the reform was shaped 'by the need to create a narrative to legitimise and defend the share of the CAP budget' in the MFF (2015: 169); (2) there was a condensed negotiation window because the key actors delayed finalising their 
positions on CAP reform until the budget proposals were agreed in early 2013; and (3) some aspects of CAP reform - relating to convergence and greening for example - were included in the MFF itself (with a subsequent impact on the decision making process).

In essence, the broad lines of the reform were set out in the MFF, leaving the Agriculture Council to fill in the specific details. While there were disagreements between austerity-minded countries (Germany and the UK wanted a squeeze on the total budget) and those who wanted to keep agricultural spending at the existing level (e.g. France, Italy and Spain), the outcome of the MFF was that as a percentage of the budget, spending on the CAP will decrease slowly to around a third of the total by 2020 (the absolute figures remain relatively stable). As the Commission noted, this showed 'continued strong support for an ambitious agricultural policy' (2013: 3), and it also 'surprised and delighted farm groups' (Matthews 2015: 171). Crucially the MFF maintained the 75:25 spending ratio between pillar 1 and pillar 2, which was a setback for countries such as the UK which wanted a reorientation of funds from direct payments to rural development programmes - indeed the negotiations resulted in a reduction on the original plans of around two per cent for pillar 1 but by nearly eight per cent for pillar 2 .

Key objectives for the Commission were to combine a 'greener and more equitably distributed' first pillar alongside a second pillar 'more focussed on competitiveness and innovation, climate change and the environment' (2011a: 16). As well as making the CAP more efficient and effective, a core aim was for a fairer distribution of payments - across pillars, between farmers (from larger to smaller enterprises) and 
between 'old' and 'new' member states. To do this, the approach had three main elements - convergence, capping, and greening - and combined compulsory requirements with voluntary options. The extent to which this approach can meet the objectives set is still unclear (especially in relation to redistribution) but what is clear is that the reform has substantially extended the ability of member states to tailor the CAP to their own conditions (e.g. for regionalising the basic payment, continuing 'coupled' support, providing assistance for small farmers, 'capping' and the reduction of payments, and environmental sustainability).

In the distribution of resources, member states can strike different balances between pillar 1 and pillar 2. For most countries, up to 15 per cent of national envelopes can be transferred in either direction and are not restricted to increasing funding for rural development (some are allowed to transfer up to 25 per cent). Eleven member states have decided to transfer funds to pillar 2, mostly at a rate of less than 5 per cent each year (only the UK and Estonia will apply relatively high rates of transfer at 10.8 and 15 per cent respectively). Five member states (mainly in eastern Europe) opted to transfer funds to pillar 1, with Poland transferring the maximum 25 per cent. Overall the net funding gain for pillar 2 will be $€ 3$ bn over six years (European Commission 2016: 4), a very small amount in relation to the total funding.

Within the suite of direct aid schemes, the Basic Payment Scheme (BPS), young farmers' scheme, and the greening payment are compulsory; countries (and regions within them) also have flexibility to implement a 'redistributive payment', introduce voluntary coupled support schemes (VCS), and support measures in areas with natural constraints (ANC). Only Denmark has chosen to implement the ANC 
payment, whereas all countries except Germany have opted to use VCS, covering a whole range of production sectors but especially beef and dairy (11 member states have allocated the maximum 13 per cent, 9 have allocated less than 8 per cent). Fifteen 'countries' have decided to adopt the new simplified 'small farmers' scheme (that replaces all of the other direct payments schemes for the beneficiaries concerned). The overall impact of this enhanced flexibility (or 'renationalisation') is that both the structure of the CAP in member states and the share of funding allocated to different schemes can 'vary significantly throughout the EU' (European Commission 2013: 7; 2016: 20).

A central reform aim for the Commission was 'convergence' to narrow variations in direct payments across countries, particularly between old and 'new' Europe ('external' convergence), and between producers with 'fairer treatment of farmers performing the same activities' ('internal' convergence)(European Commission 2011a: 16). French and Spanish ministers had strong reservations about this because they feared that redistribution would reduce the benefits received by their own farmers (a Commission estimate put this as high as a seven per cent reduction for French farmers). Consequently they wanted a more careful phasing in of convergence and complained that the 'magnitude' and 'pace' proposed by the Commission was 'not acceptable' (Euractiv.com 2012b).

The restructuring of the architecture for direct payments is the principal mechanism for achieving convergence. For external convergence, national envelopes are adjusted to bring them closer to the EU average; increased for those where the average payment is below 90 per cent of the EU average, correspondingly adjusted 
downwards for those member states receiving more than the average. A minimum average national or regional payment (at least 75 per cent of the EU average) will be achieved by 2019. For 'internal convergence' the intention is that payments under the BPS within member states become more uniform. For example countries may decide to introduce a flat rate at either national or regional level from 2015, or to achieve this by 2019, or to increase the payments to those farms receiving less than 90 per cent of the average (with each payment entitlement normally reaching a minimum of 60 per cent of the average by 2019). No farmer receiving payments above the average will lose more than 30 per cent of their entitlements (European Commission 2015a). Among the eighteen member states implementing the BPS (ten 2004 entrants continue to apply the flat rate Single Area Payment until 2020), six opted for regionalising the payments (including Germany and the UK), four countries/regions (including Germany and England) introduced the flat rate from 2015, five (including both Scotland and Wales) will apply the flat rate from 2019, and the others will apply a partial convergence by 2019 (European Commission 2015a: 7).

A hotly disputed element of the reform was the proposal for 'capping' - the introduction of a maximum ceiling on payments - which had been fiercely resisted in previous reform episodes by countries with efficient and large scale enterprises such as the UK and France. The Commission proposed that payment levels should 'progressively converge' and payments to large beneficiaries subject to 'progressive capping' to improve the distribution of payments between farmers (2011b: 3). Reductions (degressivity) would start at 20 per cent for entitlements between $€ 150,000$ and $€ 200,000$, gradually increasing in three stages to a 100 per cent 
reduction at a maximum ceiling for payments of $€ 300,000$. The final compromise reform allowed substantial flexibility to member states across a range of decisions. While all are required to reduce payments above $€ 150,000$ at a minimum rate of 5 per cent, member states have the choice about whether to cap payments. Fifteen 'countries' (only England in the UK) will apply the minimum reduction, whereas nine will apply a cap at different rates on amounts ranging from $€ 150,000$ (including Ireland and Poland) to $€ 600,000$ in Scotland. Italy introduced a 50 per cent reduction at $€ 150,000$ and 100 per cent at $€ 500,000$; Wales opted for the most graduated system, starting at 15 per cent over $€ 150,000$, increasing in stages to a 100 per cent reduction at $€ 300,000$. It is estimated by the Commission that these decisions will transfer over $€ 500 \mathrm{~m}$ to rural development between 2015 and 2019 (European Commission 2016: 8 $\& 21)$.

Within direct payments, countries can adopt a voluntary 'redistributive payment' to favour smaller holdings by diverting up to 30 per cent of the national envelope to farmers on the first thirty hectares of land (European Commission 2016: 10). Countries that introduce a redistributive element at a rate of at least five per cent are not required also to reduce payments. Nine countries/regions (but only Wales in the UK, and Wallonia in Belgium) introduced the redistributive measure, of which six (including France) coupled this with no reduction of payment. Poland, Bulgaria and Wales decided to introduce the redistributive payment alongside the reduction of payments mechanism (European Commission 2016: 8).

The greatest controversy surrounded the proposals for 'greening', in which 30 per cent of direct payments within pillar 1 are conditional on 'environmentally 
supportive practices' with farmers receiving payments to deliver public goods (European Commission 2011a: 16). These practices were to include crop diversification (the 'three crop rule'), maintenance of permanent grassland, and the preservation of ecological reserves and landscapes. However the original proposals were considerably altered in the negotiations (see below). Here also member states have considerable flexibility in relation to policy choices, for example about the ratio of permanent grassland, whether to adopt the 'equivalence mechanism', the number and types of designated ecological focus areas (EFA), and the rules for making the payment (European Commission 2016: 14-18).

In other areas, the desire to foster market competitiveness was reflected in the removal of remaining production limits and the introduction of measures to facilitate co-operation between producers. Although market intervention remains as a safety net, and the last remaining export subsidies are reduced to zero, the force of renewed arguments about food security underpinned decisions to retain some production quotas - for sugar until 2017 (two years later than their planned abolition) and a new vine planting scheme after 2016 was introduced.

\section{A 'post-exceptional' CAP?}

Four indicators for assessing the extent of movement to a post-exceptional agricultural policy were identified above, so how does the 2013 CAP reform fare in relation to these? 


\section{New Institutions and Structures}

Compartmentalization has been a central feature of agricultural exceptionalism, but constitutional change provides one avenue for 'institutional broadening' (for example the integration of agriculture into other regimes such as environmental protection). An important factor in the CAP reform process was the new institutional structure brought in by the Lisbon Treaty, in which 'co-decision' was extended to the CAP (see Greer 2013; Greer and Hind 2012). The European Parliament (EP) is now a formal co-actor in the agricultural policy process, sharing legislative power with the Council of Ministers. The 2013 CAP reform was the first major agricultural policy dossier to be subject to co-decision. Between April and June 2013 more than forty 'trialogue' discussions took place - informal tripartite bargaining between the three main institutions before the opening of formal conciliation negotiations. An interinstitutional deal was reached in June 2013 and the Agriculture Council then adopted the reform package without discussion following a first reading agreement with the EP.

For Swinnen and Knops, the entry of the EP as a 'new player' in decision-making resulted in 'a reshuffle of the rules of the game, with new coalition opportunities and inter-institutional transfers of power' (2014: 73). However, the parallel negotiations on the MFF restricted the EP's room for manoeuvre and 'set the overall framework' within which it negotiated with the Council (Swinnen and Knops 2014: 17). Codecision certainly prolonged the policy process - with agreement reached around two years after the Commission published its legislative proposals - and the 
implementation of most of the reforms was delayed until 2015, rather than 2014 as planned.

In advance of the reform, Greer and Hind (2012) sketched out some scenarios for how inter-institutional relationships might be reconfigured under co-decision. These included the possibility that the EP would gain influence at the expense of both Commission and Council (the 'conventional' scenario), and that a dominant CouncilEP axis would develop. Some observers conclude that inter-institutional bargaining weakened the influence of the Commission and enhanced that of the Council Presidency (Matthews 2013), but there is no clear consensus among actors and commentators about which scenario best summarises the 'reality'. As reported in a study by the Centre for European Policy Studies, (using an interview sample of 34 actors composed mainly of those working in the EP, but also including some working in the Commission, the Council and from civil society), 40 per cent favoured the conventional scenario, 30 per cent believed that the other institutions gained power, and a quarter said that none of the scenarios described the process particularly well (Swinnen and Knops 2014: 74).

Overall the evidence indicates that the policy process on CAP reform has been substantially altered in terms of its institutional structures at the EU level, and that new patterns of inter-institutional policy-making have emerged. The question however is whether this has been accompanied by the entry of new actors and ideas in the policy subsystem. 


\section{New Actors $\mathcal{E}$ Interests}

Agricultural exceptionalism buttresses the interests of food producers, structured in dominant policy communities. Post-exceptionalism would see the emergence of actor constellations of a more 'issue-network' type that include 'players from a wider range of backgrounds' such as consumer, environmental and animal welfare groups, and slow food activists. However conflict is not inevitable and coalition building e.g. between farmers and environmentalists - may form around exceptionalist ideas. Paradoxically, while this can help to stabilize the ideational framework, it may also indicate a movement towards post-exceptionalism (Daugbjerg and Feindt, Introduction to this issue: 9).

Despite the institutional changes around the CAP it is not clear that the policy subsystem has substantially opened up to a wider range of actors and interests. Certainly the EP has a greater formal role in CAP decision-making, but the extent to which this indicates a post-exceptional agricultural politics is debatable. Importantly the work of the EP is itself 'compartmentalised', with a crucial role for functional committees such as the Agriculture and Rural Development standing committee (COMAGRI). Although its membership reflects the political balance of the Parliament as a whole, it is dominated by farming, landowning and rural interests (Greer and Hind 2012). So co-decision may actually have strengthened farmer bias insofar as the political centre of gravity of COMAGRI lies, around 'centre to-right farmer-friendly parties', its geographic orientation 'around a group of countries 
traditionally favouring an interventionist interpretation of the $\mathrm{CAP}^{\prime}$ (RoedererRynning 2015: 354).

While the Commission conducted what it presented as an 'inclusive' public consultation and debate at the beginning of the reform process in 2010, it is not clear that 'new' actors and interests had much influence on the outcome. Overall the influence of civil society actors was limited; environmental actors for example believe that their influence was at best marginal and that farm interests dominated the debate. However, this view is not universally shared. Co-decision did intensify contacts between the EP and stakeholders generally, so it may have opened up the relatively closed subsystem to some degree, albeit in an indirect way. Indeed the 'broadening of interests', which some observers such as Greer and Hind (2012) had speculated about in relation to COMAGRI, 'might have actually happened via the emergence of a European civil society' (Swinnen and Knops 2014: 72).

\section{New values and ideas}

The importance of a changed constellation of actors depends partly on the assumption that this will bring with it new values and policy ideas. As Richardson has noted, new ideas pose a particular threat to established policy communities because they can 'disrupt existing policy systems, power relationships and policies' (2000: 1017-8). In agricultural policy, this usually has been taken to mean a challenge

to the preferences of the established productivist policy community, and to core ideas such as the notion that supporting the farm sector is vital to the broader 
national interest, especially in relation to food security and the role of stable farm incomes in underpinning rural communities (Skogstad 1998: 468).

In ideational terms, post-exceptionalism might be indicated by greater influence for market liberal ideas, but these may be absorbed and re-interpreted in a way that preserves the notion that the sector is special. While in previous CAP reforms, policy windows were forced open by developments in relation to trade liberalisation and enlargement, the 2013 version was relatively insulated from wider exogenous pressures. For example Daugbjerg notes that the World Trade Organisation (WTO) is only referred to briefly in the Commission's original CAP reform communication, that domestic concerns were prioritised, and that pressure from the WTO 'vanished' when the Doha Round stalled in late 2008 (2016: 12). On the other hand, exceptionalism may be strengthened by connecting agriculture to 'new overarching discourses such as sustainability and globalization, and cross-cutting concerns such as the environment, climate change and food security' (Daugbjerg and Feindt, Introduction to this issue: 9). In the 2013 CAP reform there is some evidence of collaboration between groups representing farmers and environmentalists in resisting the extension of market liberalism and in protecting budgets. Overall however, analysis suggests that the EP's formal role in decision making buttressed the established policy subsystem and that the changed institutional structure around the CAP did not facilitate the introduction of new values and ideas. Swinnen and Knops remark for example that most policy ideas within the EP were 'little more than a return to the market regulation instruments of the past', influenced by agricultural exceptionalism and 'justified by arguments relating to food security and 
economic crisis' (2014: 14 \& 95). As Matthews (2013) further notes, the notion that the $\mathrm{EP}$ 'would bring new ideas to the debate and help to widen the range of interests that could influence agricultural policy also proved to be hopelessly naïve'.

\section{Policy change}

The fourth indicator for the emergence of post exceptional agricultural policy making relates to policy instruments and programmes. Exceptionalism was characterised by some specific policy mechanisms such as payments for production, tariffs and quotas, and intervention buying to stabilize prices. Certainly there has been a move away from these instruments over the last thirty years, indicated by the removal of many 'trade distorting' market support mechanisms, the introduction of 'decoupled' direct payments, and pillar 2 measures such as agri-environment schemes, often justified using rhetoric about the provision of public goods. In the 2013 CAP reform, the Commission placed particular emphasis on promoting market competitiveness, convergence and capping to promote fairer distribution of resources, and the 'greening' of a substantial element of direct payments. While this may be viewed as consistent with a post-exceptional direction of travel, the retention of some market intervention instruments and the introduction of voluntary coupled support schemes (that have been adopted by over twenty countries), seem to suggest the persistence of older logics around food security. In convergence and capping some countries also have exploited the flexibility allowed to reinforce more traditional exceptionalism. The ideas for 'greening' in particular were the subject of 
much debate and controversy. While environmentalists were sceptical about the impact of the 'limited greening' proposed by the Commission, for farmers the proposals undermined the EU's capacity to meet food security objectives, and some governments including France and Spain argued for a 'flexible' system in which it would be possible to have 'agriculturally sustainable use of areas of ecological interest' (Euractiv.com 2012a).

The agreed reform markedly watered down the Commission's proposals on greening; indeed some even suggest that the outcome was 'a step backwards for the integration of environmental concerns into the CAP' (Hart 2015: 246). According to a spokesperson for the European Environmental Bureau (EEB), while the proposals sowed 'some green shoots of hope', these were 'quickly cut down' in the interinstitutional bargaining. By 'trying to exempt as many farmers as possible from the most basic agronomic practices, they diluted the content of the greening measures and added dozens of grounds for exemption to already very weak rules' (Defossez 2014). There are no EU-wide performance standards, member states have flexibility in implementation, and a range of exceptions relating to water pollution, ecological focus areas, crop diversification and environmental sustainability were introduced. So although a core principle of the original proposals was that greening should apply to all farms, nearly half of all farmland and 89 per cent of farmers will not be covered by the rules (for a full discussion of the greening outcomes see Hart 2015: 263-9).

This 'greenwashing' was largely a result of the inter-institutional bargaining between the EP and Council, although the interplay between them was complex. 
Both were concerned about the impact of greening on competitiveness, production and food security, and supported plans to introduce 'greater flexibility', reflecting concerns expressed by farming stakeholder groups about 'being locked into standardised environmental rules despite the diverse landscape of European agriculture' (Spence 2013). Within COMAGRI, environmental considerations 'were drowned out by concerns about agricultural production effects' and there were few environmental interests in the EU institutions 'that saw much to be gained from a protracted defence of proposals whose environmental delivery looked likely to be disappointing' (Hart 2015: 271-2). As a spokesperson for BirdLife Europe complained, 'Europe is offered a budget that scales back investment in the environment and caters for the usual fat cats that have been milking the system' (Harrabin 2013). So while environmental groups helped to fend off some proposals such as paying farmers twice for carrying out the same activity in pillar 1 and pillar 2 - their influence overall was weak.

\section{Post-Exceptional Agricultural Policy?}

In this analysis, four indicators for assessing whether agricultural policy can be described as post-exceptional have been applied to the 2013 CAP reform. The evidence is mixed. It is plausible to argue that (1) new institutional structures apply to agricultural policy, (2) that as a result of the Lisbon Treaty some new actors and interests are involved in the decision process, and (3) that there has been some further (if weak) extension of programmes and instruments in a direction consistent 
with post exceptionalism. On the other hand, this has not been accompanied by substantial change in the ideational and value framework.

For Commissioner Cioloş, the reform was a 'paradigm shift' with its focus on greening, a fairer system of redistribution, and the reinforcement of the concept of public money for public goods (quoted in House of Commons 2013: 6). Certainly it is possible to identify an aim for some radical change, even if the Commission saw its proposals as striking a mid-position between gradual adjustment and far-reaching reform. However while some important policy changes were introduced, these arguably fit better with incremental shift in the established policy direction rather than radical re-design. For critics such as the UK Environment Secretary, Owen Patterson, the agreement did not even advance the reform trajectory started by MacSharry and continued by Fischler, or reinforce the emphasis on public goods; indeed there were some areas 'where we definitely go backwards', for example with the reintroduction of coupled payments (House of Commons 2013: 6). Greening also was markedly watered down and how extensive will be any redistribution of resources as a result of capping and convergence remains unclear.

Essentially the changed institutional and actor context did not go hand-in-hand with ideational and more extensive policy change because the decision rules and institutional structures around the $\mathrm{CAP}$, plus the balance of forces between member states - most of whom like the CAP - still works as a barrier against radical change (see Greer 2013 for a discussion of the preferences of member states). Co-decision, and the MFF agreement (as well as the weak influence of exogenous factors such as trade liberalisation), reinforced the existing policy subsystem rather than open it up 
to new influences and ideas. So despite the changed context, policy ideas and programmes were not affected in a way that substantially weakened the preferences of the established policy subsystem. As Matthews argues, once the threat of a budget cut in the MFF had receded, the institutional structure favoured those such as farm groups who took 'a status quo position on the reform proposals' while disadvantaging those 'who sought a more radical change' (2015: 178). For Erjavec et al. the rhetoric around the reforms hid the desire of a conservative block 'to extend the re-distributional logic of the CAP within a still comprehensive budget while implementing as few paradigmatic changes as possible' (2015: 236).

It seems clear then, in terms of the ideational underpinnings of those actors who were influential in the reform process, that the dominant motivation was the desire to support farm production and farm incomes. As Erjavec et al. suggest, although the Commission's core aims emphasised the environment and climate change (for example at least 30 per cent of spending in pillar 2 rural development programmes must be reserved for such measures), they were reinterpreted in ways that preserve the CAP (2015: 232). So while an alternative discourse about environmental sustainability and climate change was present, this was heavily outweighed by productivist objectives and a traditional discourse that emphasised food production and food security.

Issues about rural development, environmental sustainability and climate change have all been integrated to some degree within the CAP in recent years, and there is some evidence to support post-exceptionalism in terms of changed institutional structures and actors. Overall however the policy impact has been weak and the 
ideational framework little altered. The analysis of the 2013 CAP reforms in this contribution views them as consistent with a sequencing in which an older policy heritage around food production and security is reasserted, rather than a substantial shift to reflecting non-productivist concerns. Indeed farm incomes arguably continue to be the main driving force underpinning the CAP, as illustrated by trade dispute between the EU and Russia a result of the conflict in Ukraine (the EU response to a Russian embargo on agricultural products was to provide a $€ 500 \mathrm{~m}$ relief package for farmers hit by falls in prices as a result of the loss of export markets)(European Commission 2015b).

It is important to note, however, that with greater flexibility for countries, different national patterns may emerge, with some moving at a faster rate than others towards post-exceptionalism in agriculture. After the 2013 reforms, what exists in relation to the CAP is still an 'agricultural' policy subsystem, albeit one that exhibits both continuity and change. The CAP reform illustrates what might be described as 'shallow' post-exceptionalism, insofar as there has been some shift from a historically persistent agricultural policy subsystem with the inclusion of new institutions and actors/interests, some limited change in policy programmes and instruments, but leaving the ideational framework around redistribution and farms subsidies largely intact.

Biographical note: 
Alan Greer is Associate Professor in Politics and Public Policy at UWE Bristol. His main research interests lie in the field of public policy analysis and governance, especially relating to agriculture, food and climate change.

Contact details

Department of Health \& Social Science

University of the West of England

Frenchay Campus

Bristol BS16 1QY

tel: +44 (0) 1173282422

email: alan.greer@uwe.ac.uk

\section{References}

Ackrill, R. (2000) 'CAP reform 1999: a crisis in the making?' Journal of Common Market Studies 38(2): 343-53. 
Burrell, A. (2009) 'The CAP: Looking Back, Looking Ahead', Journal of European Integration 31(3): 271-89.

Coleman, W., Skogstad, G. and Atkinson, M. (1997) 'Paradigm Shifts and Policy Networks: Cumulative Change in Agriculture', Journal of Public Policy 16: 273-301.

Cunha, A. with Swinbank, A. (2011) An Inside View of the CAP Reform Process: Explaining the MacSharry, Agenda 2000, and Fischler Reforms, Oxford: Oxford University Press.

Daugbjerg, C. (2016) 'Responding to Non-Linear Internationalization of Public Policy: The World Trade Organization and Reform of the CAP 1992 - 2013', Journal of Common Market Studies: 1-16

Daugbjerg, C. (2009) 'Sequencing in public policy: the evolution of the CAP over a decade', Journal of European Public Policy 16(3): 395-411.

Daugbjerg, C. and Swinbank, A. (2009) 'Ideational Change in the WTO and its Impacts on EU Agricultural Policy Institutions and the CAP', Journal of European Integration 31(3): 311-27.

Defossez, F. (2014) 'Environment group condemns EU “greenwashing” of CAP reform', The Parliament Magazine 18 June.

Erjavec, E., Lovec, M. and Erjavec, K. (2015) 'From “Greening” to "Greenwash": The drivers and discourses of CAP 2020 "reform"', in J. Swinnen (ed.), The Political Economy of the 2014-2020 Reforms of the Common Agricultural Policy: an Imperfect Storm, 
Brussels \& London: Centre for European Policy Studies/Rowman \& Littlefield International, pp. 215-44.

Erjavec, K., Erjavec, E. and Juvancic, L. (2008) 'New wine in Old Bottles: Critical Discourse Analysis of the Current Common EU Agricultural Policy Reform Agenda', Sociologia Ruralis 49(1): 41-55.

Euractiv.com (2012a) 'France, Germany in joint call to freeze EU farm budget', 11 October, available at http:/ / www.euractiv.com/cap/france-germany-agree-keep$\underline{\text { eu-far-news-515325 }}$

Euractiv.com (2012b) 'Spain joins France in bid to ring fence CAP budget', 15 February, available at http://www.euractiv.com/cap/spain-joins-france-bid-ringfenc-news-510824

European Commission (2016), Direct payments 2015-2020 Decisions taken by Member States: State of play as at June 2016 - Information note, available at

https://ec.europa.eu/agriculture/sites/agriculture/files/direct-support/directpayments/docs/simplementation-decisions-ms-2016_en.pdf

European Commission (2015a), Direct Payments: the Basic Payment Scheme from 2015. Convergence of the value of payment entitlements ('Internal Convergence'), available at http://ec.europa.eu/agriculture/sites/agriculture/files/direct-support/directpayments/docs/internal-convergence_en.pdf 
European Commission DG Agri (2015b), The Russian ban on EU agricultural products 12 months on, Press Release 07/08/2015, available at https://ec.europa.eu/agriculture/newsroom/218_en

European Commission (2013) 'Overview of CAP Reform 2014-2020', Agricultural Policy Perspectives Brief no. 5, Brussels: Commission of the European Communities, available at

http://ec.europa.eu/agriculture/policy-perspectives/policy-briefs/05_en.pdf

European Commission (2011a) 'Communication from the Commission to the European Parliament, the Council, the European Economic and Social Committee and the Committee of the Regions, A Budget for Europe 2020', COM(2011) 500 final, Part I, 29 June, Brussels: Commission of the European Communities, available at http://ec.europa.eu/health/programme/docs/maff-2020_en.pdf

European Commission (2011b) 'Proposal for a regulation of the European Parliament and of the Council on the financing, management and monitoring of the Common Agricultural Policy', COM(2011) 628/final/2, 19 October, Brussels: Commission of the European Communities, available at

http://eur-lex.europa.eu/legalcontent/EN/TXT/PDF/?uri=CELEX:52011PC0628R(01)\&from=EN

European Commission (2011c) 'Impact Assessment: Common Agricultural Policy towards 2020: Assessment of Alternative Policy Options', Commission Staff Working 
Paper, SEC(2011) 1153 final/2, 20 October, Brussels: Commission of the European

Communities, available at

http://ec.europa.eu/agriculture/sites/agriculture/files/policy-

perspectives/impact-assessment/cap-towards-2020/report/full-text_en.pdf

European Commission (2010) 'The CAP towards 2020: meeting the food, natural resources and territorial challenges of the future', $\operatorname{COM}(2010) 672$ final, 18 November, Brussels: Commission of the European Communities, available at

http://eur-

lex.europa.eu/LexUriServ/LexUriServ.do?uri=COM:2010:0672:FIN:en:PDF

Grant, W. (2004) 'Pressure Politics: The Changing World of Pressure Groups', Parliamentary Affairs 57(2): 408-19.

Grant, W. (1997) The Common Agricultural Policy, Basingstoke: Palgrave.

Greer, A. (2013) 'The Common Agricultural Policy and the EU budget: stasis or change?' European Journal of Government and Economics 2(2): 119-136.

Greer, A. (2012) 'Reform of the EU Budget: Implications for the Common Agricultural Policy', in G. Benedetto and S. Milio (eds.), European Union Budget Reform: Institutions, Policy and Economic Crisis, Basingstoke: Palgrave Macmillan, pp. $103-121$.

Greer, A. (2005) Agricultural Policy in Europe, Manchester: Manchester University Press. 
Greer, A. and Hind, T. (2012) 'The Lisbon Treaty, agricultural decision-making and the reform of the CAP: an analysis of the nature and impact of "co-decision"', Politics and Society 31(4): 331-41.

Harrabin, R. (2013), 'EU budget deal for farmers raises wildlife concerns', BBC News 12 February, available at http://www.bbc.co.uk/news/science-environment$\underline{21424957}$

Hart, K. (2015) 'The Fate of Green Direct Payments in the CAP Reform Negotiations', in J. Swinnen (ed.), The Political Economy of the 2014-2020 Reforms of the Common Agricultural Policy: an Imperfect Storm, Brussels \& London: Centre for European Policy Studies/Rowman \& Littlefield International, pp. 245-76.

House of Commons, Environment, Food and Rural Affairs Committee (2013) 'Implementation of the Common Agricultural Policy in England 2014-2020', Seventh Report of Session 2013-14, vol. 1, HC 745-I, London: The Stationery Office Limited.

Jordan, G., Maloney W. and McLaughlin, A. (1994) 'Characterizing Agricultural Policy-Making', Public Administration 72(4): 505-526.

Kay, A. (2003) 'Path dependency and the CAP', Journal of European Public Policy 10(3): 405-20.

Keeler, J. (1996) 'Agricultural power in the European Community: explaining the fate of CAP and GATT negotiations', Comparative Politics 28(2): 127-49. 
Lynggaard K. and Nedergaard, P. (2009) 'The Logic of Policy Development: Lessons Learned from Reform and Routine within the CAP 1980-2003', Journal of European Integration 31(3): 291-309.

Marsh, D. and Smith, M. (2000) 'Understanding policy networks: towards a dialectical approach', Political Studies 48(4): 4-21.

Matthews, A. (2015), 'The Multi-Annual Financial Framework and the 2013 Cap Reform', in J. Swinnen (ed.), The Political Economy of the 2014-2020 Reforms of the Common Agricultural Policy: an Imperfect Storm, Brussels \& London: Centre for European Policy Studies/Rowman \& Littlefield International, pp. 169-191.

Matthews, A. (2013), 'The Cioloş CAP Reform', CAP Reform.EU, 17 December, available at http:/ / capreform.eu/the-Ciolos-cap-reform/

Richardson, J. (2000) 'Government, interest groups and policy change', Political Studies 48(5): 1000-1025.

Rieger, E. (2000) 'The Common Agricultural Policy: politics against markets', in H. Wallace and W. Wallace (eds), Policy-making in the European Union, Oxford: Oxford University Press, pp. 180-210.

Roederer-Rynning, C. (2015), 'COMAGRI and the "CAP after 2013" Reform: In search of a collective sense of purpose', in J. Swinnen (ed.), The Political Economy of the 2014-2020 Reforms of the Common Agricultural Policy: an Imperfect Storm, Brussels \& London: Centre for European Policy Studies/Rowman \& Littlefield International, pp. 331-56. 
Roederer-Rynning, C. (2010), 'The Common Agricultural Policy: the Fortress Challenged', in Helen Wallace, Mark Pollack and Alastair Young (Eds.), PolicyMaking in the European Union (6th ed.). Oxford: Oxford University Press, pp. 181-206.

Rutz, C., Dwyer, J. and Schramek, J. (2014) 'More new wine in old bottles? The evolving nature of the CAP debate in Europe, and prospects for the future', Sociologica Ruralis 54(3): 266-84.

Skogstad, G. (1998) 'Ideas, Paradigms and Institutions: Agricultural Exceptionalism in the European Union and the United States', Governance 11: 463-90.

Smith, M. (1992) 'The agricultural policy network: maintaining a closed relationship', in R. Rhodes and D. Marsh (eds), Policy networks in British government, Oxford: Clarendon Press, pp. 27-50.

Smith, M. (1991) ‘From Policy Community to Issue Network: Salmonella in Eggs and the New Politics of Food', Public Administration 69: 235-255.

Spence, T. (2013), 'CAP 2014-2020: A long road to reform', Euractiv.com, 4 July available at

http://www.euractiv.com/section/agriculture-food/linksdossier/cap-2014-2020-a$\underline{\text { long-road-to-reform/ }}$

Swinbank, A. (2012) 'Another Reform? Proposals for the post-2013 Common Agricultural Policy', World Agriculture: problems and potential 3(1): 32-37.

Swinbank, A. (1999) 'EU agriculture: Agenda 2000 and the WTO commitments', World Economy 22(1): 41-54. 
Swinnen, J. (2015)(ed.), The Political Economy of the 2014-2020 Reforms of the Common Agricultural Policy: an Imperfect Storm, Brussels \& London: Centre for European Policy Studies/Rowman \& Littlefield International.

Swinnen, J. (2009)(ed.) The Perfect Storm: The Political Economy of the Fischler Reforms of the Common Agricultural Policy, Brussels: Centre for European Policy Studies.

Swinnen, J. and Knops, L. (2014), 'The First Cap Reform Under The Ordinary Legislative Procedure: A Political Economy Perspective', Centre for European Policy Studies (CEPS), A study prepared for the European Parliament's Committee on Agriculture and Rural Development. IP/B/AGRI/IC/2013-156.

Wilkinson, K., Lowe, P. and Donaldson, A. (2010) ‘Beyond Policy Networks: Policy Framing and the Politics of Expertise in the 2001 Foot and Mouth Disease Crisis', Public Administration 88(2): 331-345.

Winter, M. (2003) 'Responding to the Crisis: the Policy Impact of the Foot-andMouth Epidemic', Political Quarterly 74(1): 47-56.

Woods, M. (2005), Contesting Rurality: Politics in the British Countryside, Aldershot: Ashgate. 